\title{
INTERPERSONAL RELATION SEBAGAI VARIABEL YANG MENENTUKAN KINERJA UNIT ATAU ORGANISASI
}

\author{
J.A.A. Rumeser \\ Jurusan Psikologi, Fakultas Psikologi, Bina Nusantara University \\ Jln. Kemanggisan Ilir III No 45, Kemanggisan, Palmerah, Jakarta Barat 11480
}

\begin{abstract}
Every organization, require maintenance or improvement of performance for institutional sustainability. To maintain or improve performance, various kinds of business or methods developed. Various methodologies always involves a person or human element in organizations. Deepening and understanding of performance, will greatly assist the organization. When talking about performance in an organizational context, it is not sufficient if we only look at the paradigm in which individual capabilities we need to also look at the paradigm of interactions between individuals. To this we can turn to the model developed from HPT. From the discussion we propose a model that combines these two things, namely, the performance of $(K)=$ individual resources (SDI) + interaction effectiveness (EI).
\end{abstract}

Keywords: performance, HPT, interaction effectiveness

\begin{abstract}
ABSTRAK
Setiap organisasi, memerlukan penjagaan atau peningkatan kinerja untuk kelanggengan institusinya. Untuk menjaga atau meningkatkan kinerja ini, berbagai macam usaha ataupun metode dikembangkan. Berbagai metodologi tersebut selalu melibatkan unsur orang atau manusia dalam organisasi. Pendalaman dan pemahaman mengenai pencapaian kinerja, akan sangat membantu organisasi. Saat berbicara tentang kinerja dalam konteks organisasi, maka tidak memadai bila kita hanya melihat dari paradigma kapabilitas perorangan di dalamnya kita perlu juga melihat dari paradigma bagaimana interaksi antara individunya. Untuk ini kita dapat berpaling pada model yang dikembangkan dari HPT. Dari pembahasan kami mengusulkan model yang menggabungkan kedua hal tersebut, yaitu, kinerja $(K)$ = sumber daya individual $(S D I)+$ efektivitas interaksi (EI).
\end{abstract}

Kata kunci: kinerja, HPT, efektivitas interaksi 


\section{PENDAHULUAN}

Bagi banyak organisasi, performance atau kinerja menjadi kata yang dirindukan sekaligus memilukan. Dirindukan karena setiap kinerja menggambarkan pencapaian dan keberhasilan. Memilukan bila indikator kinerja menunjukkan gambaran yang tidak sesuai dengan harapan atau target. Untuk menjaga atau meningkatkan kinerja ini, berbagai macam usaha ataupun metode dikembangkan. Beberapa hal yang lazim dilakukan antara lain adalah Balanced Score Card, Benchmarking, Business Process Reengineering, Learning Organization, Management by Objective dan, Total Quality Management (TQM). Untuk organisasi nirlaba yang biasa digunakan adalah Outcome Based Evaluation (McNamara, 2008).

Berbagai metodologi diatas dalam eksekusinya akan selalu melibatkan unsur orang atau manusia dalam organisasi. Manusia adalah sumber daya utama dalam menciptakan kinerja di organisasi (Drucker, 2007). Perhatian utama bagi psikologi, khususnya psikologi industri dan organisasi (psikologi I/O), adalah bahwa pendalaman dan pemahaman mengenai pencapaian kinerja, akan sangat membantu organisasi maupun pengelola atau manager dalam menganalisis, dan kemudian menyusun langkah langkah penanganan atau intervensi yang terarah dan terfokus pada unsur yang sungguh sungguh berpengaruh pada kinerja.

Sangat kita sadari bahwa psikologi sebagai disiplin ilmu yang mempelajari perilaku manusia dan proses mental (Laley, 2007; Passer dan Smith, 2004; Ciccarelli dan Meyer, 2006; Wieten, 2008) akan memberi kontribusi yang bermakna dalam penanganan kinerja suatu organisasi. Bila kita lihat, berbagai cara atau pendekatan dalam menjaga dan mendorong peningkatan kinerja, banyak bersumber dari area manajemen. Oleh karena itu peristilahan yang lazim digunakan adalah Performance Management. (deWall, 2001; Drucker, 2007). Walaupun demikian disiplin manajemen juga menengarai pentingnya unsur manusia dalam pencapaian kinerja (Kanter, 1997). Bersamaan dengan itu, juga disadari bahwa manusia sebagai sumber daya memiliki karakteristik yang unik dan berbeda dengan sumber daya lainnya. (Drucker, 2007).

Salah satu keunikannya adalah, manusia merupakan sumber daya yang paling mobile, artinya manusia adalah subyek yang dapat pergi atau pindah dengan kehendak sendiri. Berdasarkan pertimbangan di atas, maka patutlah kiranya kita melihat bahwa diperlukan suatu tinjauan dan pendalaman tentang variabel manusia atau manusia yang menghasilkan kerja organisasi. Sekurangkurangnya ada 2 (dua) alasan utama untuk mendalami masalah ini. Pertama, kinerja merupakan suatu hal yang penting bagi organisasi. Baik organisasi bisnis maupun organisasi nirlaba. Kedua, unsur atau variabel penting dalam menghasilkan kinerja adalah manusia. Dalam hal ini disepakati bahwa manusia merupakan sumber daya yang unik dan berbeda dari sumber daya lainnya.

Lebih jauh bila kita lihat, maka tinjauan terhadap masalah kinerja seseorang di organisasi hampir selalu mengambil sudut pandang yang tertuju pada kualitas individual, seperti ramuan model yang dikembangkan oleh Parker \& Turner, dari gagasan Blumberg \& Pringle, (1982) dan Neal \& Griffin, (1999). Pada dasarnya model ini hendak menggambarkan bahwa terdapat berbagai faktor yang mempengaruhi kinerja orang didalam organisasi. Salah satunya adalah faktor individual, seperti kepribadian, preferensi, toleransi terhadap ambiguitas peran dan lain-lain. Sisi lain dari kinerja adalah tempat individu berkarya, yaitu organisasi. Seperti kita pahami organisasi adalah suatu wadah dari sekelompok orang yang bertujuan untuk menghasilkan sesuatu atau mencapai sasaran yang telah disepakati, secara terkoordinasi (Daft, 2004; Jones, 2006).

Lebih jauh, organisasi selain berkeinginan untuk mencapai sasaran yang disepakati, tentu juga berkeinginan untuk mempertahankan kelanggengannya. (Drucker, 2007; De Wall, 2001). Oleh karena itu kinerja menjadi sangat penting. Bahkan pada titik tertentu untuk dapat bertahan dan berkembang, 
organisasi perlu menggeser paradigmanya untuk tidak tergantung pada hal-hal yang tradisional, seperti unsur fisik dan keuangan. (Luthans, et al, 2007). Dikatakannya bahwa kita perlu bertumpu pada human and social capital, yang disebutnya sebagai psychological capital.

Di sini dapat kita lihat bahwa unsur sumber daya manusia mengambil peran yang penting. Oleh karena itu dapat kita katakan bahwa penanganan kinerja yang bertumpu pada unsur sumber daya manusia menjadi sesuatu yang bermakna bagi organisasi. Secara ringkas dapat dikatakan, asumsi yang digunakan adalah bahwa kinerja kelompok atau organisasi akan meningkat bila kualitas orang perorang juga meningkat. Hal ini terlihat jelas pada model HPT (Human Performance Technology), seperti pada Gambar 1 berikut.

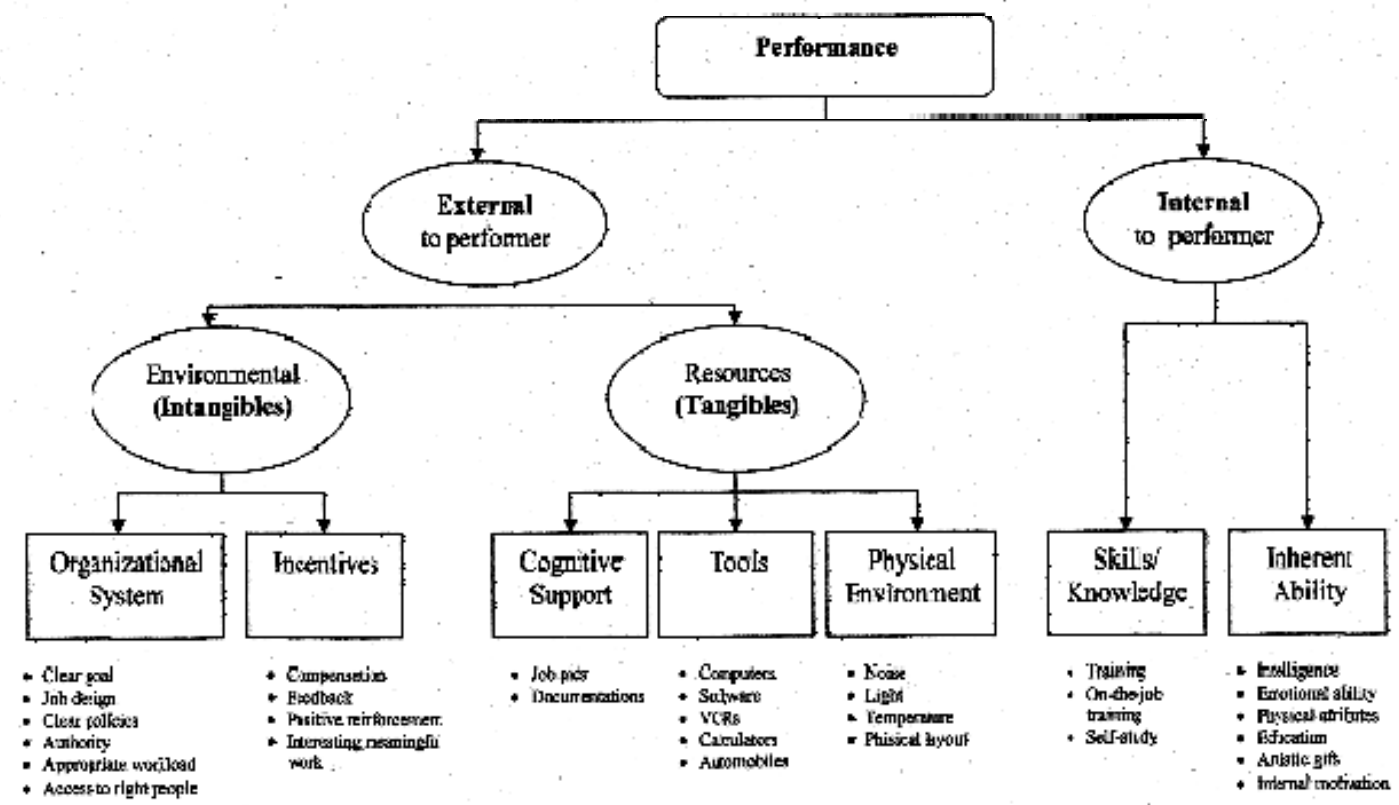

Gambar 1 Model HPT (Human Performance Technology)

Sumber: Wilmont et al (2002)

Hal ini didukung oleh hasil scanning yang dilakukan oleh Sonnentag \& Frese (2002) terhadap 14 jurnal yang terkait dengan masalah kinerja. Melalui meta-analisis yang dilakukan, diperoleh gambaran bahwa 51,5\% pembahasan kinerja selalu terkait dengan kinerja perorangan sebagai konsep inti. Dari telaahan lebih lanjut (Sonnentag \& Frese, 2002) juga menemukan bahwa sebanyak 72,5\% dari pembahasan tersebut meletakkan kinerja perorangan sebagai variabel-dependen.

Gambar 1 menunjukkan bahwa penanganan kinerja yang berbasiskan orang per-orang, kurang memperhatikan unsur organisasi yang terdiri dari kelompok orang. Seperti diketahui bahwa kelompok atau organisasi yang terdiri dari orang orang dengan kapabilitas tinggi tidak selalu menghasilkan keluaran yang tinggi. Selama ini, untuk meningkatkan kinerja organisasi maka yang di 'otak-atik' adalah orang per-orang. Menurut hemat kami, kenyataan ini menunjukkan bahwa selama ini telah terjadi lompatan dalam pengambilan kesimpulan. Ada rantai yang terputus yang perlu menjadi perhatian agar kinerja atau keluaran kelompok dapat lebih baik, dan mata rantai yang terputus inilah yang perlu ditemukan. 


\section{METODE PENELITIAN}

Tulisan ini dirangkai berdasarkan observasi yang kemudian diolah melalui suatu kajian pustaka sehingga dapat menjadi suatu kajian ilmiah.

\section{HASIL DAN PEMBAHASAN}

Berbagai kajian terkait kinerja dapat dikelompokkan ke dalam dua alur besar. Alur pertama adalah yang bersifat makro atau sering juga dikatakan sebagai tinjauan stratejik. Alur kedua adalah yang bersifat mikro, yaitu manuver dan unsur unsur yang langsung terkait dengan kegiatan dalam organisasi, di sinilah bahasan tentang kinerja perorangan dilakukan. Pembahasan tentang kinerja di sini secara mayoritas terkait dengan variabel yang bersifat individual perorangan. Pertanyaan yang sering dilontarkan bila berbicara tentang kinerja adalah: Bagaimana motivasinya? Bagaimana kepribadiannya? Bagaimana intelegensinya?

Semua pertanyaan di atas diletakkan dalam konteks organisasi. Seperti sudah disebutkan sebelumnya, di sini terkandung makna bahwa peningkatan kualitas individual atau perorangan akan secara otomatis meningkatkan kinerja organisasi atau unit kerja. Menurut kami ini adalah lompatan kesimpulan yang terlalu cepat. Hal inilah yang menjadi pusat pembahasan penulisan ini. Penulisan ini akan melihat bahwa ada unsur lain yang perlu diperhatikan apabila kita berbicara tentang kinerja perorangan dalam konteks unit kerja. Secara khusus ini dimaksudkan bahwa peningkatan kinerja dalam organisasi yang fokus pada kualitas kualitas pribadi seperti tipe kepribadian dan inteligensi, belum mencukupi. Hal ini terkait dengan definisi organisasi yang menggambarkan bahwa organisasi memaknai adanya interaksi antara anggota organisasi. Melalui pembahasan ini maka usaha-usaha peningkatan kinerja akan mempunyai perspektif yang lebih komprehensif, yaitu selain memperhatikan kualitas perorangan, juga memperhatikan hakekat organisasi.

\section{Organisasi}

Pertanyaan mengenai, apakah organisasi itu? Selalu dijawab dengan awalan yang melukiskan bahwa organisasi adalah sesuatu yang kompleks dan multi dimensi. (Veen \& Korver, 1998). Walaupun ada beberapa perbedaan dalam mendefinisikan tetapi para pakar mempunyai kesepakatan tentang hal-hal yang utama dalam pengertian organisasi., yaitu, pertama, organisasi adalah sebuah entitas sosial. Kedua, organisasi mempunyai arah atau sasaran yang ingin dicapai. Ketiga, organisasi ditata sedemikian rupa sehingga merupakan sistem yang terstruktur dan terkoordinasi. Keempat, organisasi juga mempunyai keterkaitan dengan lingkungannya. (Daft, 2004). Pendapat serupa juga dapat dilihat pada Jones (2004), Robbins \& Judge (2007), Greenberg \& Baron (2008).

Kesimpulan yang dapat diambil adalah, organisasi merupakan kumpulan perorangan yang ingin mencapai sesuatu yang bernilai. Dalam konsep psikologi, organisasi dapat dipadankan dengan konsep Gestalt (Ciccarelli \& Meyer, 2006; Passer \& Smith, 2004). Konsep ini memaknakan bahwa keseluruhan bukanlah semata-mata penjumlahan dari unsur-unsurnya. Melalui perkenalan dengan teori Gestalt maka organisasi mempunyai makna yang menggambarkan adanya keterkaitan antara unsurunsur yang terkandung di dalamnya.

\section{Konsep Dasar Kinerja (Performance)}

Bila kita lihat pada APA Dictionary of Psychology (2007), maka performance diartikan sebagai (1) any activity or collection of responses that leads to a result or has an effect upon the environment; (2) the behavior of an organism (the performer) when faced with a specific task (hal. 
685). Melalui definisi tersebut, berarti bahwa berkinerja adalah rangkaian usaha dan aktivitas yang mengarah pada pencapaian sesuatu. Ini berarti ada kesejajaran makna dengan arti atau pengertian organisasi.

Pada awal tahun 1990-an ada kesepakatan tentang makna dari performance, yaitu, mencakup tindakan atau action sebagai aspek perilaku dan outcome yang merupakan hasil yang diperoleh (Campbell, 1990; Campbell, McCloy, Oppler \& Sager, 1993; Roe, 1999). Secara singkat dapat dikatakan bahwa bila membicarakan perilaku atau behavioral aspects, maka kinerja diartikan sebagai tindakan kerja misalnya membersihkan mesin, memasang suku cadang atau memeriksa laporan keuangan. (Sonnentag \& Frese, 2002). Secara tegas Campbell et al (1993) mengatakan, "Performance is what the organization hires one to do and do well" (hal 40). Berarti di sini ada unsur judgement. Sementara outcome aspects adalah hal-hal yang terjadi sebagai dampak dari perilaku atau tindakan seseorang. Misalnya tindakan memeriksa laporan keuangan berdampak terhadap adanya laporan keuangan yang dapat dipertanggungjawabkan dan dapat mencegah penyimpangan atau penyelewengan. Bersamaan dengan itu dapat dilihat bahwa outcome aspects tidak semata-mata tergantung pada tindakan orang per orang, tetapi juga terdapat aspek lain. Misalnya dalam hal pemeriksaan laporan keuangan, bila ada persekongkolan maka dampak atau outcome yang diharapkan tidak terjadi. Walaupun secara konseptual kedua aspek dari performance dapat dibedakan tetapi secara kenyataan sehari-hari, hal ini sangat sulit dipisahkan.

Hal berikut yang dilontarkan adalah bahwa outcome juga sangat tergantung pada perilaku perorangan. Oleh karena itu maka amat realistis bila kinerja organisasi dikaitkan dengan perilaku dan kinerja perorangan. (Campbell, et al, 1993; Sonnentag \& Frese, 2002). Pembahasan lebih jauh adalah tentang kinerja yang berbasiskan individual behavior. Hal ini dapat dilihat dari 2 (dua) dimensi. Menurut Borman \& Motowidlo (1997), dimensi itu adalah task performance dan contextual performance. Yang tergolong task performance adalah hal-hal yang terkait dengan masalah teknis pekerjaan. Sementara contextual performance adalah hal-hal yang tidak berdampak langsung terhadap teknis pekerjaan, seperti inisiatif menata ulang prosedur atau menjadi karyawan yang loyal (Motowidlo dan Schmit, 1999). Kemungkinan lain dalam melihat performance adalah dengan melihatnya dari tiga perspektif. (Sonnentag \& Frese, 2002; Kanfer, 1992). Masing-masing perspektif adalah individual perspective, situational perspective dan performance regulation perspective. Yang dimaksud dengan individual perspective adalah hal-hal seperti pengetahuan, ketrampilan ataupun motivasi. (Kanter et al, 1997; Campbell, 1990). Sementara situational perspective adalah hal hal yang dapat memacu dan dapat menghambat kinerja. Melalui penelaahan ini maka dapat diperoleh gambaran tentang situasi yang membuat seseorang dapat menampilkan kinerja terbaiknya. Studi yang mewakili pandangan tentang perspektif ini antara lain expectancy theory dari Vroom (1964) atau Lawler (2000) yang mengembangkan studi tentang faktor-faktor khusus yang memotivasi kerja seseorang. Demikian juga studi yang dilakukan Hackman \& Oldham (1976), yang meneliti tentang task identity, task significance atau feedback yang mempengaruhi keadaan psikologis seseorang. Seperti perasaan dihargai atau rasa tanggung jawab terhadap hasil kerja.

Adapun performance regulation perspective sebagai perspektif yang ketiga, adalah perspektif yang berbeda, dalam arti perspektif ini tidak melihat kepada individu ataupun situasi yang mempengaruhi kinerja, tetapi perspektif ini memusatkan perhatian pada proses kinerja itu sendiri (Sonnentag \& Frase, 2002). Contohnya studi-studi yang dilakukan oleh Ericsson \& Lehmann (1996), tentang kinerja dan sudut pandang psikologi kognitif. Salah satu hasil penting dari studi tentang bagaimana proses berkinerja ini adalah ditemukannya bukti bahwa ada perbedaan antara pendekatan kerja para high performer dibandingkan dengan para moderate performer. Disini juga ditemukan perbedaan bagaimana para high performer mencapai suatu solusi. (Sonenntag, 2000). Biasanya para high performer mulai dari hal-hal yang bersifat informasi yang abstrak dan umum menuju ke yang lebih spesifik. Hal lain yang berbeda adalah para high performer lebih terfokus pada sasaran jangka panjang. 


\section{Faktor Penentu Kinerja}

Secara umum para pakar psikologi industri dan organisasi sangat tertarik pada masalah job performance dan job satisfaction. Pada awalnya banyak studi dilakukan untuk melihat keterhubungan kausal antara kedua variabel tersebut. Hal ini dipicu oleh berkembangnya aliran human relation yang mengasumsikan bahwa pekerja yang produktif adalah pekerja yang bahagia (Roethlisberger, 1941). Aliran ini bermula dari suatu studi terkenal di Hawthorne yang dilakukan oleh Elfon Mayo (Schultz dan Schultz, 2006). Hasil studi pimpinan Mayo inilah yang pertama kali berhasil membuktikan adanya pengaruh psikologis atau non fisik terhadap kinerja.

Diskusi tentang hal ini makin menajam ketika Herzberg, Mausner, Snyderman (1959) membedakan antara faktor hygiene dan faktor motivator. Intinya ia membedakan antara dissatisfaction dengan no satisfaction. Permasalahan yang dimunculkan oleh Hezberg, walaupun memunculkan kontroversi, juga menstimulasi upaya untuk menemukan model yang dapat lebih menjawab masalah penentu kinerja yang tinggi. Salah satu model adalah high-performance cycle (HPC), yang dikembangkan oleh Locke dan Latham (1990). Untuk memudahkan penjelasan mengenai model ini, dapat kita lihat pada Gambar 2 berikut.

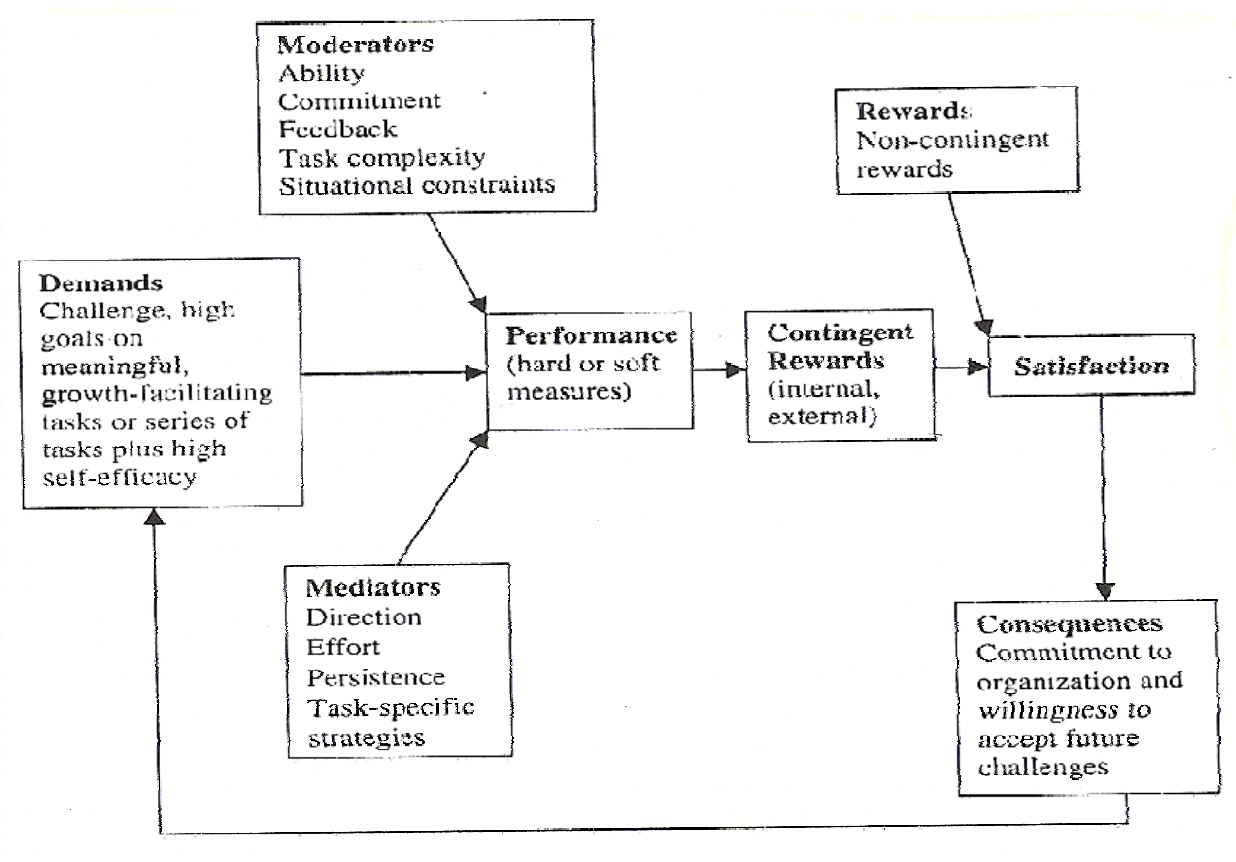

Gambar 2 High Performance Cycle (HPC)

Sumber: Locke dan Latham (1990)

Model ini mengklaim bahwa HPC merupakan model yang komprehensif yang dapat menjelaskan hubungan sebab akibat, berdasarkan temuan-temuan hasil riset (Latham, Locke, Fassina, 2002). Bila dilihat pada model ini, dapat dikatakan bahwa unsur-unsur di dalam faktor demands, mediators dan moderators adalah hal-hal yang dalam berbagai riset berhasil dibuktikan perannya. Walaupun HPC dari Latham dan Locke (1990) ini dapat menjawab bagaimana menghasilkan kinerja yang tinggi, tetapi model ini tetap belum dapat menjawab bagaimana peran kinerja perorangan yang tinggi dalam konteks unit atau organisasi. 


\section{Kinerja dan Human Capital}

Pershing (2006), mengatakan bahwa untuk melihat kinerja dalam konteks organisasi, dapat kita lihat pada hasil kerja 2 (dua) pemenang nobel, Theodore Schultz pemenang tahun 1979 dan Gory Becker pemenang tahun 1992. Kedua tokoh ini memenangkan nobel dalam bidang ekonomi, yang studi studinya terkait dengan human capital. Oleh karena pembahasannya dalam perspektif ekonomi, maka unsur human disini dilihat melalui tema yang makro. Stolovitch \& Keeps (2006) menyatakan, "By human capital, we mean the sum total of all knowledge, experience, and performance capability an organization posses that can be applied to create wealth" (hal xviii).

Sejajar dengan rumusan di atas, maka berkembanglah apa yang disebut sebagai human performance technology (HPT). Dipelopori oleh Gilbert (1978), yang melontarkan gagasan tentang human competence, dia menyimpulkan bahwa human competence adalah fungsi dari worthy performance (W) yang dihasilkan dari rasio antara valuable accomplishment (A) dengan costly behaviour (B). Stolovitch (1982) mengartikan HPT sebagai bidang yang mencari perubahan sistem agar sistem tersebut dapat memiliki nilai yang lebih baik.

Harless (1988) merumuskan HPT secara lebih spesifik, yaitu sebagai suatu proses seleksi, analisis, disain, pengembangan, implementasi dan evaluasi dari program, agar diperoleh suatu pendekatan yang paling cost efficient dalam menangani human behaviour. Para pakar sesudah Harless, seperti Langdon (1991); Rothwell (1996); Van Tiem, Moseley, Dessinger (2004) merumuskan HPT dengan variasi tertentu. Tetapi tetap berdasarkan alur yang telah dirumuskan oleh Harles. Walaupun bertitik tolak dari konsep dasar human capital, tetapi para pakar HPT kembali lagi pada pendekatan yang sifatnya individual. Hal ini dapat dilihat dari diagram yang menjadi dasar intervensi dari para pakar HPT seperti pada Gambar 3 berikut.

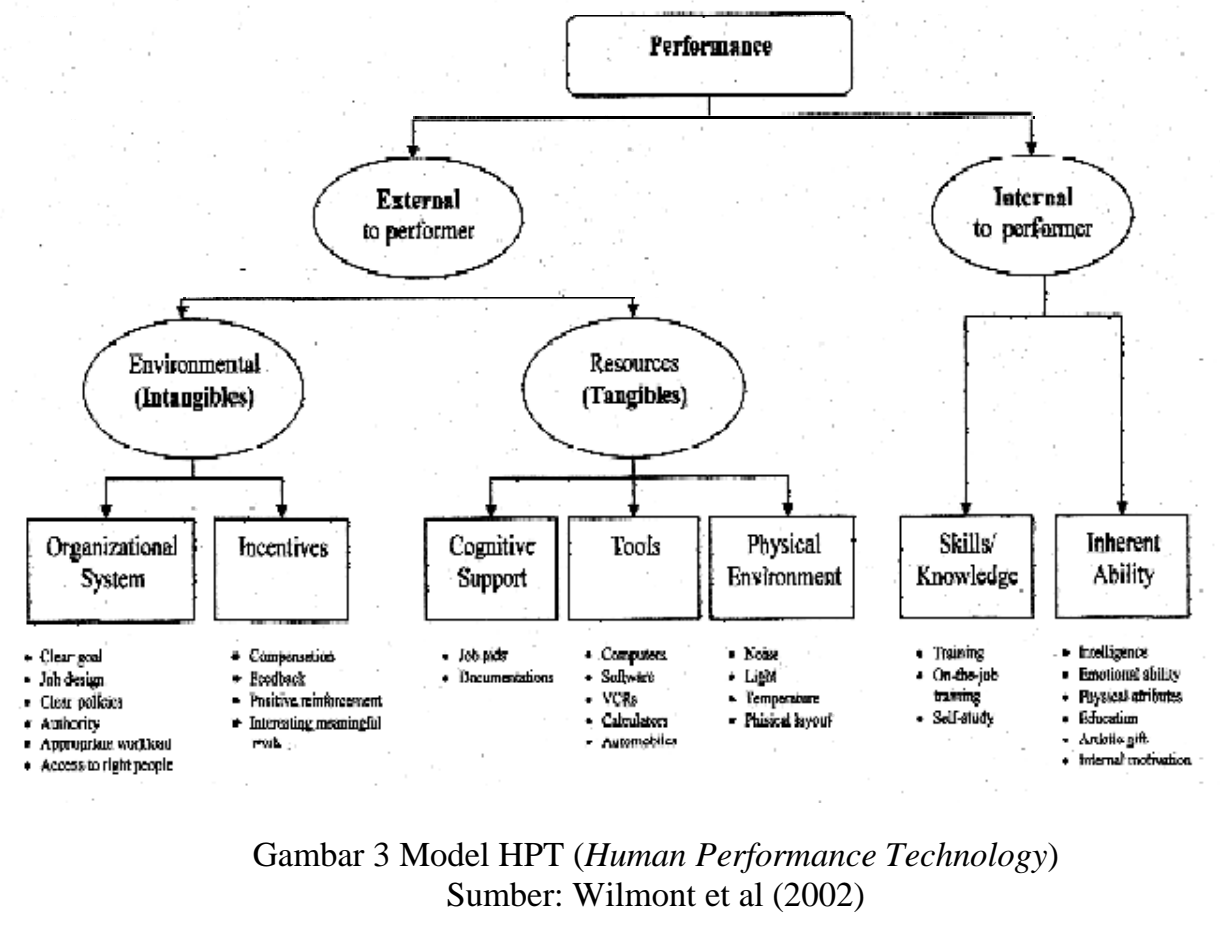

Gambar 3 secara nyata memperlihatkan bahwa dasar tinjauannya adalah meningkatkan kapabilitas individu atau perorangan. Melalui hal ini, diharapkan kinerja unit atau organisasi akan meningkat. 


\section{Kinerja dan Unsur Psikologis}

Sesungguhnya masalah non inteligensi di dalam kinerja bukanlah sesuatu yang baru. Salah satu titik awalnya adalah saat Thorndike (1920) sebagai tokoh dalam masalah inteligensi menyebutkan adanya social intelligence. Hal ini diartikannya sebagai "the ability to understand and manage men and women, boys and girls - to act wisely in human relations" (hal. 228). Sesudah Thorndike, pakar masalah inteligensi lain David Weschler (1952) menyebutkan tentang adanya affective capacities.

Selanjutnya Gardner (1983), juga melontarkan gagasan tentang multiple intelligence, salah satunya adalah personal intelligence yang di dalamnya terdapat intrapersonal dan interpersonal intelligence. Walaupun demikian, perumusan secara lebih tajam tentang unsur non cognitive ini dibuat oleh Salovey dan Mayer pada tahun 1990. Mereka menamakannya sebagai emotional intelligence (EI) yang diartikan sebagai “ability to monitor one's own and other's feelings and emotions, to discriminate among them, and use this information to guide one's thinking and action " (hal. 189).

Mengenai dampak EI terhadap kinerja, banyak studi yang mendukungnya. Cherniss \& Adler (2000) merangkum beberapa hasil penelitian, antara lain, Handley \& Bar-on (1998), yang menyampaikan bahwa recruiters dari US Air Force yang diseleksi berdasarkan EI ternyata dapat menghemat US\$ 3 juta per-tahun, juga penelitian Hunts, Schmidt \& Judiesch (1990), yang mengatakan bahwa para pekerja asuransi yang memiliki EI yang lebih tinggi, tingkat produktivitasnya mencapai $127 \%$. Selanjutnya penelitian di perusahaan kosmetik L'oreal, para sales agents yang diseleksi berdasarkan EI berhasil menjual rata-rata lebih banyak US\$ 91,370 dibandingkan sales agents pada umumnya (Spencer, McClelland \& Kelner, 1997).

Konsep yang pertama kali diperkenalkan oleh Salovey dan Mayer (1990) ini, kemudian dipopulerkan oleh Goleman (1995). Dalam penerapannya di organisasi, oleh Goleman (1998), diterjemahkan menjadi emotional competence. Model ini kemudian disempurnakan, yang awalnya terdiri dari 5 (lima) cluster, yaitu, self awareness, self regulation, motivation, empathy dan social skill, diubah menjadi hanya empat cluster, yaitu, self awareness, self management, social awareness dan relationship management (Goleman, 2001). Hal yang penting dalam model EI ini adalah dimasukannya unsur social awareness dan relationship management. Dengan dimasukannya kedua unsur tersebut, maka kinerja perorangan dalam konteks organisasi makin memperoleh bentuk yang utuh. Secara lebih jauh, kemampuan berinteraksi ini oleh Goleman (2006), disebutnya sebagai social intelligence, yang di dalamnya ada dua unsur, yaitu, social awareness, yang terkait dengan kepekaan terhadap orang lain. Unsur kedua adalah social facility, yang merupakan tindak lanjut terhadap apa yang kita tangkap.

Rumusan lain tentang hubungan antar orang atau human relationship oleh Tekleab, Takeuchi \& Taylor (2005), diartikan sebagai, bagaimana kita berhubungan dengan semua pihak lain seperti keluarga, kawan dan rekan kerja. Kraut (2006), mengutip Higgs \& Ashworth, melihat bahwa telah terjadi pergeseran fokus dari survei yang dilakukan sejak tahun 1930-an yang fokusnya adalah individual worker, sampai tahun 1990-an fokusnya bergeser kepada unit dan tim kerja. Dari perubahan ini dapat dikatakan bahwa unsur interpersonal relationship menjadi sesuatu yang perlu diperhitungkan bila kita berbicara tentang kinerja perorangan dalam konteks unit atau organisasi.

Unsur psikologis lain yang juga berpengaruh pada hasil kerja tim dapat ditemukan dalam model yang dikembangkan oleh Faraj dan Yan (2009), mereka menyebutnya sebagai 'team psychological safety'. Ini diartikan sebagai: A team's psychological safety is not a dispositional characteristic and does not emerge automatically. Rather, it is a psychological state that emerges as a result of team building efforts, as well as other environmental factors. (hal. 608). 


\section{SIMPULAN}

Berdasarkan beberapa bahasan di atas, dapat dirangkum bahwa bila kita berbicara tentang kinerja dalam konteks organisasi, maka tidak memadai bila kita hanya melihat dari paradigma kapabilitas perorangan di dalamnya kita perlu juga melihat dari paradigma bagaimana interkasi antara individunya. Oleh karena itu ada dua unsur utama yang perlu diperhatikan yaitu unsur kualitas maupun kapabilitas individual dan bagaimana interaksi antara para individu dalam organisasi atau unit kerja. Kapasitas perorangan yang bekerja dalam suatu organisasi atau unit kerja memang perlu diperhatikan. Untuk itu kita dapat berpaling pada model yang dikembangkan dari HPT. Di sisi lain kita dalam pembahasan di atas dapat kita lihat bahwa organisasi mengandung unsur adanya kegiatan terkoordinasi antara unsur-unsur individu yang terlibat di dalamnya. Hal ini sejajar dengan konsep Gestalt yang mengatakan bahwa keseluruhan bukanlah sekedar penjumlahan dari unsur-unsur yang ada didalamnya. Dalam kaitan organisasi dapat diterjemahkan bahwa hal yang menjadi pengikat untuk munculnya unsur totalitas adalah interaksi antara individu yang ada dalam unit kerja. Di sinilah dapat kita lihat makna dari konsep klasik di Indonesia tentang 'filasafat sapu lidi' berlaku. Unsur interakasi atau kapabilitas interaksi tergambar dari model yang diperlihatkan oleh Goleman (2001), terkait dengan unsur social awareness \& relationship management . Ini sekaligus memperkuat tentang pentingnya unsur interaksi dalam memahami atau menelaah kinerja organisasi atau unit kerja. Untuk itu kami mengusulkan model yang menggabungkan kedua hal tersebut, yaitu, kinerja $(\mathrm{K})=$ sumber daya individual (SDI) + efektivitas interaksi (EI).

\section{DAFTAR PUSTAKA}

Blumberg, M., \& Pringle, C. (1982). The Missing Opportunity in Organizational Research. Academy of Management Review, 7, 360-369.

Borman, W. C., \& Motowidlo, S. J. (1997). Task performance and contextual performance: The meaning for personnel selection research. Human Performance. 10, 99-109.

Campbell, J. P. (1990). Modelling the performance prediction problem in industrial and organizational psychology. In M. D. Dunnette \& L. M. Hough (Eds.), Handbook of industrial and organizational psychology. (Vol. 1, pp. 687 - 732). Palo Alto: Consulting Psychologist Press.

Campbell, J. P., McCloy, R. A., Oppler, S. H., \& Sager, C. E. (1993). A theory of performance. In E. Schmitt, W.C. Borman, \& Associates (Eds.), Personnel selection in organizations (pp. 35 70). San Fransisco: Jossey - Bass.

Cherniss, C., \& Adler, M. (2000). Promoting Emotional Intelligence in Organization. Alexandria, ASID.

Circcarelli, S. K., \& Meyer, G. E. (2006). Psychology. New Jersey: Pearson Education, Inc.

Daft, R. L. (2004). Organization Theory and Design. USA: Thomson South - Western.

Drucker, P. E. (2007). People and Performance, the best of Peter Drucker on Management. Boston: Harvard Bussiness School Press.

De Wall, A. A. (2001). Power of Performance Management. Canada: John Wiley \& Sons, Inc.

Ericsson, K. A., \& Lehmann, A. C. (1996). Expert and exceptional performance: Evidence on maximal adaptations on task constraints. Annual Review of Psychology, 47. 273-305. 
Gardner, H. (1983). Frames of Mind: The Theory of Multiple Intelligence. New York: Basic Book.

Gilbert, T. F. (1978). Human Competence: Engineering Worthy Performance. New York: McGraw Hill.

Goleman, D. (1995). Emotional Intelligence. New York: Bantam.

Goleman, D. (1998). Working with Emotional Intelligence. New York: Bantam.

Goleman, D. (2001). Emotional Intelligence: Issues in Paradigm Building. In C. Cherniss \& D. Goleman (Eds.), The Emotionally Intelligent Workplace (pp. 13-26). San Francisco, CA: Jossey-Bass.

Goleman, D. (2006). Social Intelligence. New York: Bantam.

Greenberg, J., \& Baron R. A. (2008). Behavior in Organization. New Jersey: Pearson Education, Inc.

Hackman, J. R., \& Oldham, G. R. (1976). Motivation through the design of work: Test of a theory. Organizational Behavior and human performance, 16, $250-279$.

Harless, J (1988). Accomplishment-Based Curriculum Development. Newnan, GA: Harless Performance Guild.

Handley, R. \& Bar-On, R. (1998). "Military Recruiting: The Department of Defense Could Improve Its Recruiter Selection and Incentive Systems" Submitted to Congress January 30, 1998.

Hunter, J. E., Schmidt, F. L., \& Judiesch, M. K. (1990). Individual Differences in Output Variability as a Function of Job Complexity. Journal of Applied Psychology, 75, 28-42.

Herzberg, F., Mausner, B., \& Snyderman, B. B. (1959). The Motivation to Work (2nd ed.). New York: John Wiley \& Sons.

Ilgen, D. R., \& Schneider, J. (1991). Performance measurement: A multy-discipline view. In C. L. Cooper, \& I. T. Robertson (Eds.), International review of industrial and organizational psychology (Vol. 6, pp. $71-108$ ). Chichester: Wiley.

Jones, G. R. (2004). Organizational Theory, Design, and Change. New Jersey: Pearson Education.

Jones, M. D. (2006). Which is a Better Predictor of Job Performance: Job Satisfaction or Life Satisfaction. Institute of Behavioral and Applied Management, 20 - 42.

Kanter, R. M. (1997). Frontiers of Management. Boston: Harvard Business School Press.

Kraut, A. (Eds). (2006). Getting action from organizational surveys-new concepts, technologies and application. San Fransisco: John Wiley \& Son.

Lahey, B. B. (2007). Psychology: an Introduction. New York: McGraw Hill.

Langdon, D. (1991). Performance technology in three paradigms. Performance and Instruction Journal, 30(7), 1-7.

Latham, G. P., Locke, E. A., \& Fassina, N. E. (2002). The high performance cycle: Standing the test of time. In S. Sonnentag (Ed.), Psychological management of individual performance (pp. 201228). Chichester, England: Wiley. 
Lawler, E. E. I. (2000). Rewarding Excellence: Pay Strategies for the New Economy. San Fransisco, CA: Jossey Bass.

Locke, E. A., \& Latham, G. P. (1990a). A theory of goal setting and task performance. Englewood Cliffs, NJ: Prentice-Hall.

McNamara, C. (2008). Basic guide to outcomes-based evaluation for non-profit organizations with very limited resources. Free Management Library. Diunduh dari http://www.managementhelp.org/evaluatn/outcomes.htm

Motowidlo, S. J., \& Schmit, M. (1999). Performance Assessment in unique jobs. In D. R. Ilgen \& E. D. Pulakos (Eds.), The Changing Nature of Job Performance. San Fransisco, CA: Jossey Bass.

Neal, A., \& Griffin, M.A. (1999). Developing a Theory of Performance for human resource management. Asia Pacific Journal of Human Resources, 37, 44 - 60.

Passer, M. W., \& Smith, R. E. (2004). Psychology: The Science of Mind and Behavior. New York: McGraw Hill.

Pershing, J. A. (2006). Handbook of Human Performance Technology. San Fransisco: Pfeiffer.

Robbins, S. P., \& Judge, T. A. (2007). Organizational Behavior. New Jersey: Pearson Education.

Roe, R. A. (1999). Work Performance: A Multiple regulation perspective. In C. L. Cooper \& I. T. Robertson (Eds.), International Review of Industrial and Organizational Psychology, 14, 231 $-335$.

Roethlisbager, F. J. (1941). Management and Morale. Cambridge: Harvard University Press.

Rothwell, W. J. (1996). Beyond training and development: State-of-the-art strategies for enhancing human performance. New York: American Management Association.

Salovey, P., \& Mayer J. P. (1990). Emotional intelligence, Imagination, Cognition, and Personality, 9. 185-211.

Schultz, D., \& Schultz, S. E. (2006). Psychology \& Work Today. Boston: Pearson.

Sonnentag, S. (2000). Expertise at work: Experience and Excellent Performance. In C. L. Cooper \& I. T. Robertson (Eds.), International Review of Industrial and Organizational Psychology, 223 264. Chichester: Wiley.

Sonnentag, S., \& Frese, M. (2002). Performance Concept and Performance Theory in Psychological Management of Individual Performance. UK Sussex: John Wiley \& Sons.

Spencer, L. M. J., McClelland, D. C., \& Kelner, S. (1997). Competency assessment methods: History and state of the art. Boston: Hay/McBer.

Stolovitch, H., \& Keeps E. (1992). What is Performance Technology? In H. D. Stolovitch \& E. J. Keeps (Eds.), Handbook of Human Performance Technology: A comprehensive guide for analyzing and solving performance problems in organizations. San Fransisco: JosseyBass/Pfeiffer.

Stolovitch, H. (1982). Performance Technology: an Introduction. Performance and Instruction, 21(3), 16-19. 
Tekleab. A., Takeuchi R., \& Taylor, M. S. (2005). Extending the Chain of Relationship among Organizational Justice, Social Exchange, and Employee Reactions: The Role of Contract Violations. Academy of Management Journal, 48, 1 (2005), pp. 146-157.

Thorndike, E. L. (1920). Intelligence and Its Uses. Harper, 140, 227-235.

Van Tiem, D. M., Moseley, J. L., \& Dessinger, J. C. (2004). Fundamentals of Performance Technology. Washington, DC: International Society for Performance Improvement.

VandenBos, G. R. (2007). APA Dictionary of Psychology. Washington: American Psychological Association.

Veen, P. and Korver, T. (1998). “Theories of Organization”. In Drenth, P. J. D., Thierry, H. and Wolff, C. J. (eds) Handbook of Work and Organizational Psychology: Organizational Psychology. Brighton: Psychology Press, pp. 5-38.

Vroom, V. H. (1964). Work and Motivation. New York: Willey.

Weiten, W. (2008). Psychology: Themes \& Variation. Balmony, CA: Thomson Wadsworth.

Wilmont, F. S., Prigmore, C., \& Bray, M. (2002). HTP Models: an Overview of the Major Models in the Field. Performance Improvement, 41 (8), 14-22. 